\title{
ANALISIS KELAYAKAN AGROINDUSTRI KERIPIK KELAPA (Studi Kasus Pada PT. Dinaya Sambiana Loemintoe di Dusun Cikoranji Desa Cimindi Kecamatan Cigugur Kabupaten Pangandaran)
}

\author{
DEDE HERI GUNTARA ${ }^{1 *}$, BUDI SETIA ${ }^{1}$, SUDRAJAT ${ }^{1}$ \\ ${ }^{1}$ Fakultas Pertanian Universitas Galuh \\ E-mail: dedeheriguntara69@gmail.com
}

\begin{abstract}
ABSTRAK
Penelitian ini bertujuan untuk mengetahui : 1) Besarnya biaya produksi yang dikeluarkan PT. Dinaya Sambiana Loemintoe pada pembuatan keripik kelapa per satu kali proses produksi, 2) Besarnya penerimaan yang diterima PT. Dinaya Sambiana Loemintoe pada pembuatan keripik kelapa per satu kali proses produksi, 3) Besarnya pendapatan yang diterima PT. Dinaya Sambiana Loemintoe pada pembuatan keripik kelapa per satu kali proses produksi , 4) Besarnya R/C yang didapatkan PT. Dinaya Sambiana Loemintoe pada pembuatan keripik kelapa per satu kali proses produksi. Penelitian ini dilakukan di Dusun Cikoranji Desa Cimindi Kecamatan Cigugur Kabupaten Pangandaran dengan menggunakan Metode Studi Kasus. Dengan mengambil sampel secara purposive pada seorang pengusaha agroindustri keripik kelapa. Hasil penelitian menunjukkan bahwa: 1) Besarnya biaya produksi yang dikeluarkan PT. Dinaya Sambiana Loemintoe pada pembuatan keripik kelapa per satu kali proses produksi adalah $\mathrm{Rp}$ 8.440.907.) 2) Besarnya penerimaan yang diterima PT. Dinaya Sambiana Loemintoe pada pembuatan keripik kelapa per satu kali proses produksi adalah Rp 19.320.000. 3) Besarnya pendapatan yang diterima PT. Dinaya Sambiana Loemintoe pada pembuatan keripik kelapa dalam satu kali proses produksi Rp 10.879,093 4) Besarnya R/C yang didapatkan PT. Dinaya Sambiana Loemintoe pada pembuatan keripik kelapa per satu kali proses produksi adalah 2,28.
\end{abstract}

Kata Kunci: Biaya, Keripik Kelapa, Penerimaan, Pendapatan dan R/C

\begin{abstract}
This study aims to find out: 1) The amount of production costs incurred by PT. Dinaya Sambiana Loemintoe in making coconut chips per production process, 2) The amount of revenue received by PT. Dinaya Sambiana Loemintoe for making coconut chips per production process, 3) The amount of income received by PT. Dinaya Sambiana Loemintoe for making coconut chips per production process, 4) The amount of $R$ / C obtained by PT. Dinaya Sambiana Loemintoe for making coconut chips per production process. This research was conducted in Cikoranji Hamlet, Cimindi Village, Cigugur Subdistrict, Pangandaran Regency, using the Case Study Method. By taking samples purposively to a coconut chips agro-industry entrepreneur. The results of the study indicate that: 1) The amount of production costs incurred by PT. Dinaya Sambiana Loemintoe for making coconut chips per production process is $R p$. 8.440.907. 2) The amount of revenue received by PT. Dinaya Sambiana Loemintoe for making coconut chips per production process is Rp. 19,320,000. 3) The amount of income received by PT. Dinaya Sambiana Loemintoe for making coconut chips in one production process $R p$ 10.879,093 4) The amount of $R$ / C obtained by PT. Dinaya Sambiana Loemintoe in the manufacture of coconut chips per one-time production process is 2,28.
\end{abstract}

Keywords: Coconut Chips, Costs, Receipts, Revenues and R / C

\section{PENDAHULUAN}

Kelapa merupakan tumbuhan asli daerah tropis, yakni daerah yang terletak di sepanjang garis khatulistiwa. Di daerahdaerah tropis tersebut tanaman kelapa banyak tumbuh dan dibudidayakan oleh sebagian besar petani. Di wilayah Indonesia tanaman kelapa dapat ditemukan hampir di seluruh provinsi, dari daerah 
pantai yang datar sampai ke daerah pegunungan yang kurang tinggi. Tanaman kelapa sangat bermanfaat bagi kehidupan manusia sehari-hari. Tidak hanya buahnya, tetapi seluruh bagian tanaman mulai dari akar, batang, sampai ke pucuk tanaman dapat dimanfaatkan (Warisno, 2003).
Pangandaran menjadi salah satu Kabupaten di Jawa Barat yang berpotensi menjadi produsen kelapa, hal ini dikarenakan Kabupaten Pangandaran merupakan daerah pesisir pantai dan memiliki iklim tropis sehingga menjadi wilayah yang baik untuk tumbuhnya tanaman kelapa.

Tabel 1. Luas Tanam, Luas Tanaman Menghasilkan, Produksi dan Produktivitas Tanaman Kelapa di Kabupaten Pangandaran Tahun 2018

\begin{tabular}{llrrrr}
\hline No. & Kecamatan & $\begin{array}{c}\text { Luas Tanam } \\
\text { (Ha) }\end{array}$ & $\begin{array}{c}\text { Luas } \\
\text { Tanaman } \\
\text { Menghasilkan } \\
\text { (Ha) }\end{array}$ & $\begin{array}{c}\text { Produksi } \\
\text { (ton) }\end{array}$ & $\begin{array}{c}\text { Produktivitas } \\
\text { (Ton/Ha) }\end{array}$ \\
\hline 1. & Cigugur & $\mathbf{2 . 1 6 5 , 4 1}$ & $\mathbf{2 . 1 6 4 , 4 1}$ & $\mathbf{2 0 8 , 5 8 6}$ & $\mathbf{0 , 9 6}$ \\
2. & Cijulang & $3.834,40$ & $3.834,00$ & 442,396 & 0,15 \\
3. & Cimerak & $4.575,42$ & $5.141,78$ & 453,43 & 0,09 \\
4. & Kalipucang & $4.030,09$ & $4.029,81$ & 451,87 & 0,11 \\
5. & Langkaplancar & 543,70 & 525,70 & 546,90 & 1,04 \\
6. & Mangunjaya & 759,06 & 759,27 & 5.300 .000 & 6,98 \\
7. & Padaherang & $2.322,07$ & $2.323,43$ & 321,980 & 0,14 \\
8. & Pangandaran & $1.783,07$ & $1.783,35$ & 4,144 & 2,32 \\
9. & Parigi & $5.946,22$ & $2.819,10$ & 578,880 & 0,20 \\
10. & Sidamulih & $1.829,64$ & $1.829,64$ & 144,48 & 0,07 \\
& Jumlah & $\mathbf{2 7 . 7 8 9 , 0 8}$ & $\mathbf{2 5 . 3 6 0 , 3 8}$ & $\mathbf{1 2 . 5 9 3 , 0 0 0}$ & - \\
& Rata-rata & $\mathbf{2 . 7 7 8 , 9 1}$ & $\mathbf{2 . 5 3 6 , 0 4}$ & $\mathbf{1 . 2 5 9 , 3 0}$ & $\mathbf{0 , 4 9}$ \\
\hline
\end{tabular}

Tabel 1 menunjukkan, bahwa luas tanam pohon kelapa di Kabupaten Pangandaran seluas 27.789,08 hektar, luas tanaman menghasilkan 25.360,38 hektar, dengan produksi 12.593,00 ton, dan rata-rata produktivitasnya 0,49 .

Kecamatan Cigugur merupakan salah satu penghasil kelapa di Kabupaten Pangandaran dengan luas tanam pohon kelapa seluas 2.165,41 hektar dengan produksi 208,586 ton dan produktivitasnya 0,96 ton/ha. PT. Dinaya Sambiana Loemintoe di Dusun Cikoranji Desa Cimindi adalah satu-satunya perusahaan yang memproduksi keripik kelapa di Kecamatan Cigugur Kabupaten Pangandaran. Keripik kelapa adalah keripik yang berasal dari daging kelapa yang didapat setelah santan dihasilkan. 
Meskipun sudah menghasilkan keuntungan, namun tidak diketahui secara pasti berapa besarnya biaya, penerimaan, pendapatan dan R/C yang diperoleh PT. Dinaya Sambiana Loemintoe per satu kali proses produksi. Oleh karena itu penulis tertarik untuk untuk melakukan penelitian mengenai Analisis Biaya, Penerimaan, Pendapatan dan R/C pada Agroindustri Keripik Kelapa yang diusahakan PT. Dinaya Sambiana Loemintoe di Dusun Cikoranji Desa Cimindi Kecamatan Cigugur Kabupaten Pangandaran

\section{HASIL DAN PEMBAHASAN}

\section{Identitas Responden}

\section{Identitas Responden}

Data yang digunakan untuk memberikan gambaran umum mengenai identitas responden meliputi aspek umur, pendidikan, mata pencaharian, pengalaman berusaha dan jumlah tanggungan keluarga.

Umur Responden

Umur adalah faktor yang mempengaruhi terhadap keberhasilan dalam melakukan sutau kegiatan usaha dan juga akan berpengaruh terhadap kemampuan fisik dalam bekerja dan cara berfikir. Responden yang diambil adalah seorang perajin agroindustri keripik yang bernama Atha'ullah Dwi Payana yang berusia 47 tahun, berdasarkan umur responden berada dalam masa produktif dalam menjalankan usaha tersebut. Tingkat Pendididkan Responden

Tingkat pendidikan merupakan faktor yang sangat menentukan terhadap seseorang dalam melaksanakan kegiatan usaha, karena dalam pola pikir orang yang berpendidikan rendah sangat berbeda jauh dengan orang yang berpendidikan lebih tinggi, sehingga dalam penerimaan hal-hal yang baru lebih sulit bagi yang berpendidikan rendah, dalam suatu usaha juga ditentukan pula apakah orang tersebut bisa mengelola dengan baik atau tidak. Perajin agroindustri keripik yang berada di Desa Cimindi adalah tamat S1 Teknik Manajemen Industri, dengan pendidikan sebagai sarjana mngindikasikan bahwa pemilik usaha sudah mempunyai ilmu dasar untuk menjalankan agroindustri keripik kelapa sehingga semua kegiatan yang dijalankan dapat terencana dengan baik.

Tanggungan Keluarga Responden

Perajin usaha keripik ini memiliki tanggungan keluarga sejumlah enam orang yang terdiri dari istri dan lima orang anak, dengan tanggungan keluarga yang banyak 
responden menjadikan keripik kelapa sebagai usaha utama untuk memenuhi kebutuhan ekonomi keluarga

Pengalaman Berusaha Responden

Usaha agroindustri keripik yang beralamat di Dusun Cikoranji Desa Cimindi Kecamatan Cigugur Kabupaten Pangandaran sudah berpengalaman berusaha selama 15 tahun hal tersebut merupakan modal utama untuk keberhasilan dalam usaha agroindustri keripik kelapa.

\section{Keadaan Umum Agroindustri Keripik}

\section{Kelapa}

Pengadaan Sarana Produksi

Penyediaan sarana produksi dilaksanakan sendiri oleh responden. Bahan baku utamanya adalah kelapa yang dibeli dari petani dengan harga sebesar Rp. 1.500 per butir. Rata-rata kelapa yang diolah pada agroindustri keripik di Desa Cimindi per satu kali proses produksi sebanyak 3.000 butir.

Proses Pembuatan Keripik Kelapa

Proses pembuatan keripik kelapa terdiri dari 3 proses, yaitu:

1) Proses Pengupasan dan Pencucian a. Memilih kelapa yang cukup tua untuk dijadikan bahan baku kemudian daging kelapa dipisahkan dari tempurung.

b. Daging kelapa yang sudah dikupas dari tempurung, kemudian dikupas kulit ari yang berwarna coklat. Ini bertujuan untuk membersihkan daging kelapa sehingga akan didapat hasil potongan daging kelapa yang putih dan bersih.

c. Kemudian hasil kupasan daging kelapa dicuci bersih menggunakan air.

2) Proses Pengirisan

Kelapa yang sudah dicuci bersih kemudian diiris tipis menggunakan mesin pemotong.

3) Proses Pengovenan

a. Hasil irisan kelapa kemudian dimasukan ke ruangan khusus untuk dilakukan pengovenan.

b. Waktu yang dibutuhkan selama proses pengovenan ialah kurang lebih 4 jam hingga irisan kelapa yang tadinya basah menjadi kering seperti keripik.

c. Setelah kering, kemudian keripik kelapa dibiarkan selama 2 jam hingga dingin. 
4) Proses Pengemasan

Setelah dingin keripik kelapa siap dikemas menggunakan kantong plastik kapasitas $25 \mathrm{~kg}$, dan keripik kelapa siap dijual atau dipasarkan.

\section{Analisis Usaha Agroindustri Keripik}

\section{Kelapa}

Biaya Tetap

Biaya tetap yang dihitung dalam penelitian ini terdiri dari penyusutan alat, pajak bumi dan bangunan, dan bunga modal tetap. Hasil perhitungan menunjukkan bahwa biaya tetap total yang dikeluarkan oleh agroindustri keripik kelapa dalam satu kali proses produksi adalah Rp 396.751,44, sebagaimana dapat dilihat pada tabel 8 .

\section{Tabel 2 .Biaya Tetap Total Agroindustri Keripik Kelapa dalam Satu Kali Proses Produksi.}

\begin{tabular}{clr}
\hline No & Biaya Tetap & $\begin{array}{r}\text { Besarnya Biaya } \\
(\mathbf{R p})\end{array}$ \\
\hline 1 & PBB & 50.000 \\
2 & Penyusutan Alat & 1.412 .984 \\
3 & $\begin{array}{l}\text { Bunga Modal } \\
\text { Tetap }\end{array}$ & 102.409 \\
\hline & Jumlah & $\mathbf{1 . 5 1 5 . 3 9 3}$ \\
\hline
\end{tabular}

Tabel 2 menunjukkan bahwa besarnya biaya tetap total sebesar $\mathrm{Rp}$ 1.515.393 yang diperoleh dari penjumlahan biaya PBB sebesar Rp 50.000 biaya penyusutan alat sebesar $\mathrm{Rp}$
1.412.984 dan bunga modal Tetap $\mathrm{Rp}$ 102.409

\subsubsection{Biaya Variabel}

Adapun biaya variabel yang dihitung dalam penelitian ini meliputi biaya sarana produksi, tenaga kerja dan bunga modal variabel. Total biaya variabel yang dikeluarkan untuk sekali produksi adalah sebesar Rp 10.475.514

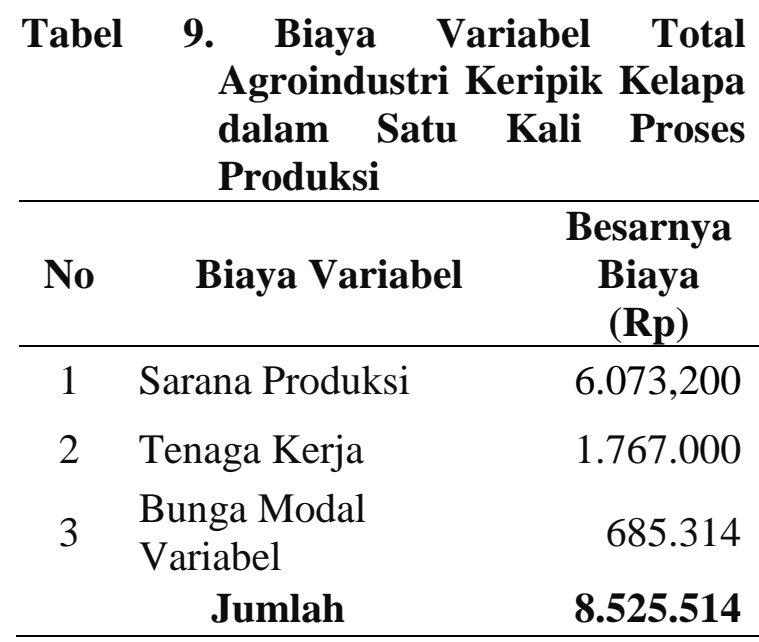

Tabel 9 menunjukkan bahwa biaya variabel total yang dikeluarkan dalam satu kali proses produksi adalah $\mathrm{Rp}$ 8.525.514 yang diperoleh dari penjumlahan biaya sarana produksi sebesar Rp 6.073,200 biaya tenaga kerja $\mathrm{Rp}$ 1.767.000. dan bunga modal variabel $\mathrm{Rp} 685.314$.

\subsubsection{Biaya Total}

Biaya total merupakan penjumlahan antara biaya tetap total dengan biaya variabel total. Untuk lebih jelasnya dapat dilihat tabel dibawah ini. 
Tabel 10. Biaya Total Agroindustri Keripik Kelapa dalam satu Kali Proses Produksi.

\begin{tabular}{llr}
\hline No & Biaya & Jumlah (Rp) \\
1 & Biaya Tetap & 1.515 .393 \\
2 & Biaya Variabel & 8.525 .514 \\
& Jumlah & \\
\hline
\end{tabular}

Tabel 10 menunjukkan bahwa biaya total yang dikeluarkan dalam pengolahan keripik kelapa dalam sekali produksi adalah Rp 10.040.907.

\section{Analisis Penerimaan Agroindustri}

\section{Keripik Kelapa}

Penerimaan adalah perkalian antara jumlah produksi dengan harga jual produk. Harga jual keripik kelapa yang diperoleh pengelola agroindustri adalah sebesar $\mathrm{Rp}$ 28.000/kg. Sedangkan produksi keripik kelapa dalam sekali proses produksi adalah sebesar 690 kg keripik kelapa. Jadi penerimaan yang diperoleh adalah sebesar Rp 19.320.000. perajin keripik kelapa yaitu penerimaan dikurangi dengan biaya produksi (biaya tetap dan biaya variabel).

\section{Analisis Pendapatan Agroindustri}

\section{Keripik Kelapa}

Besarnya pendapatan tergantung pada banyaknya yang dihasilkan serta harga jual. Hasil penelitian menunjukkan bahwa pendapatan agroindustri keripik kelapa dalam satu kali proses produksi di Desa Cimindi sebesar Rp. 10.879,093

secara lebih rinci mengenai besarnya pendapatan agroindustri keripik kelapa di Desa Cimindi, dapat dilihat pada lampiran.

\section{Analisis R/C Agroindustri Keripik Kelapa}

$\mathrm{R} / \mathrm{C}$ adalah perbandingan antara penerimaan dengan biaya. Penerimaan yang diterima oleh agroindustri keripik kelapa dalam sekali proses produksi adalah Rp 19.320.000 dan biaya yang dikeluarkan adalah sebesar Rp 8.440.907 Sehingga didapat R/C pada agroindustri pengolahan keripik kelapa adalah sebesar 2,28 Artinya setiap biaya yang dikeluarkan Rp 1 akan diperoleh penerimaan sebesar Rp 2,28 dan pendapatan sebesar Rp 1,28 oleh karena itu agroindustri keripik kelapa menguntungkan dan layak untuk diusahakan.

\section{KESIMPULAN DAN SARAN}

\section{Kesimpulan}

Berdasarkan hasil penelitian dan pembahasan dapat diambil kesimpulan sebagai berikut:

1) Besarnya biaya produksi yang dikeluarkan PT. Dinaya Sambiana Loemintoe untuk keripik kelapa per 
satu kali proses produksi adalah $\mathrm{Rp}$ 8.440 .907

2) Besarnya penerimaan yang diterima PT. Dinaya Sambiana Loemintoe pada pembuatan keripik kelapa per satu kali proses produksi adalah Rp 19.320.000.

3) Besarnya pendapatan tergantung pada banyaknya yang dihasilkan serta harga jual. Hasil penelitian menunjukkan bahwa pendapatan agroindustri keripik kelapa dalam satu kali proses produksi di Desa Cimindi sebesar Rp $10.879,093$

4) Besarnya R/C yang didapatkan PT. Dinaya Sambiana Loemintoe pada pengolahan keripik kelapa per satu kali proses produksi adalah 2,28.

\section{Saran}

Berdasarkan kesimpulan penelitian, maka diajukan saran sebagai berikut :

1) Agroindustri sebaiknya tetap melakukan produksi keripik kelapa.

2) Sebaiknya dilakukan perincian perusahaan baik itu pencatatan biaya, penjualan, penerimaan dan pendapatan.

3) Diharapkan ada peningkatan produksi sehingga diharapkan adanya peningkatan pendapatan bagi pengelola perusahaan.
DAFTAR PUSTAKA

Anjani, E. Dan Haryanto. 2009. Geografi untuk Kelas X SMA/MA. Jakarta: PT Cempaka Putih

Arikunto, S. 2006. Metode Penelitian Kualitatif. Jakarta: Bumi Aksara

Darsono, 2008. Metodologi Riset Agribisnis Buku II Metode Analisis Data. Progam Studi Magister Manajemen Agribisnis Progam Pascasarjana UPN. Veteran. Surabaya

Desa Cimindi, 2018. Data Wilayah dan Penduduk Desa Cintakarya Tahun 2017. Kabupaten Pangandaran

Dinas Pertanian, 2018. Luas Tanaman, Produksi, dan Produktivitas Tanaman Kelapa Dalam Tahun 2017. Kabupaten Pangandaran.

Gustiyana, H. 2003. Analisis Pendapatan Usahatani Untuk Produk Pertanian. Salemba empat, Jakarta.

Hansen \& Mowen. 2002. Manajemen biaya. Edisi Bahasa Indonesia. Buku 1. Jakarta : Salemba Empat

Indriyani, dkk. 2017. Analisi Biaya, Pendapatan dan $R / C \quad P a d a$ Agroindustri Serundeng Kelapa. Kab. Ciamis

Lanchance, P and M.R Milona. 1974. Nutritive Value of Viber Free Coconut Protein Extract Obtained By Enzyme-Chemical Method. Journal of Food Science. Volume 39, Issue 3 Pages 581-584.

Mantra. 2000. Demografi Umum. Pustaka Pelajar. Yogyakarta 
Meddiati Fajri Putri, 2014. Kandungan Gizi dan Sifat Fisik Tepung Ampas Kelapa Sebagai Bahan Pangan Sumber Serat. Jurnal Teknologi Busana dan Boga, Vol 1 No.1. Diakses tanggal 08 Mei 2018

M. Nafarin. 2009. Penganggaran Perusahaan. Penerbit Salemba4. Jakarta

Nursuci, S. 2012. Teknologi Budidaya Tanaman Kelapa. CV. Amaliah Book. Bandung.

Rahim, A dan Hastuti, D. 2008, Pengantar Teori dan Kasus Ekonomi Pertanian. Penebar Swadaya. Jakarta.

Riyanto, 2011. Buku Ajar Metodelogi Penelitian. Jakarta: EGC

Soekartawi. 2002. Pengantar agroindustri. Raja Grafindo Persada. Jakarta.

- 2010. Agribisnis: Teori dan Aplikasinya. Jakarta : PT Raja Grafindo Persada. 238 hal.

Sugiono, D. 2006. Statistika Untuk Penelitian. CV. Alfabeta. Bandung.

Sumiarti, Murti et al., Dasar-dasar Ekonomi Perusahaan, Edisi II,
Penerbit Liberty, Yogyakarta, 1987, Hal 60.

Suprapto, T. 2011. Pengantar Ilmu Komunikasi dan Peran Manajemen Dalam Komunikasi. Caps. PT Buku Seru. Jakarta.

Suratiyah. 2006. Ilmu Usaha Tani. Penebar Swadaya: Depok.

Suriawira, 2002. Perbandingan Pendapatan Petani Kopra Jemur dan Kopra Asap (Studi Kasus Desa Paslaten Satu Kecamatan Tatapaan). AgriSosialEkonomiUnsrat. ISSN 19074208, Volume 13 Nomor 2A, Juli 2017 : 317-322. Diakses Tanggal 12 Februari 2019

Suryani, 2012. Perilaku Konsumen dan Komunikasi Pemasaran. Remaja Rosdakarya : Bandung

Warisno, 2003. Budidaya Kelapa Genjah. Kanisius. Yogyakarta

Wikipedia, Tanaman Kelapa. https://id.m.wikipedia.org/wiki Itanaman-kelapa. Diakses pada tanggal 06 Maret 2018 